\title{
PERAMALAN VOLUME EKSPOR KELAPA SAWIT INDONESIA
}

\author{
Astia \\ Program Studi Agribisnis Fakultas Pertanian UNISI \\ Email: mudrikamumud@gmail.com
}

\begin{abstract}
ABSTRAK
Kelapa sawit merupakan salah satu komuditas ekspor unggulan di Indonesia. Untuk mengetahui berapa berapa jumlah permintaan ekspor kelapa sawit maka diperlukan peramalan yang tepat agar sesuai dengan jumlah produksi yang ada di Indonesia.Tujuan peneitian ini adalah: 1) Untuk mengetahui metode peramalan yang paling sesuai untuk meramalkan volume ekspor kelapa sawit Indonesia, 2) Untuk mengetahui nilai ramalan volume ekspor kelapa sawit Indonesia pada tahun 2016-2020. Penelitian ini menggunakan data sekunder. Metode analisis yang digunakan adalah metode peramalan time series (Semi RataRata, Trend Moment dan Regresi Linier Sederhana). Hasil penelitian menunjukkan: 1) Metode peramalan yang paling sesuai untuk meramalkan volume ekspor kelapa sawit Indonesia adalah metode Semi Rata-Rata berdasarkan kelayakan yang dimilikinya (memiliki nilai MAD dan MAPE terkecil dibandingkan dengan metode lainnya) dengan nilai MAD sebesar 2.993.848,29 dan nilai MAPE sebesar 2,79\%, 2) Berdasarkan perhitungan menggunakan metode Semi Rata-Rata diketahui bahwa volume ekspor kelapa sawit Indonesia pada tahun 2016 sampai 2020 mengalami peningkatan dengan pertumbuhan ratarata sebesar 3,33\% per tahun, tahun 2016 sebesar $20.210 .795,3$ ton, tahun 2017 sebesar 20.917.126,55 ton, tahun 2018 sebesar 21.623.457,79 ton, tahun 2019 sebesar 22.329.789,03 ton dan tahun 2020 sebesar 23.036.120,27 ton.
\end{abstract}

Kata Kunci : Kelapa sawit, Peramalan, Time Series, Trend, Ekspor,

\begin{abstract}
The purpose of this research are : 1) To determine the most appropriate forecasting method to forecast Indonesian palm oil export volume, 2) To forecast the value of Indonesian palm oil export volume in 2016-2020. This research used secondary data. The analysis method used in this research is time series forecasting (Semi Average Method, Trend Moment and Simple Linear Regression). The results of the research showed: 1) The most appropriate forecasting method to forecast Indonesian palm oil export volume is Semi Average Method based on the feasibility of its (has value of MAD and MAPE smallest compared to other methods) with value of MAD is at 2.993.848,29 and value of MAPE is at $2,79 \%, 2$ ) Based on Semi Average Method known that
\end{abstract}


Indonesian palm oil export volume in 2016 to 2020 increased with average growth of $3,33 \%$ per year, in 2016 amounted to $20.210 .795,3$ tons, in 2017 amounted to 20.917.126,55 tons, in 2018 amounted to 21.623.457,79 tons, in 2019 amounted to $22.329 .789,03$ tons and in 2020 amounted to $23.036 .120,27$ tons.

Keywords : Palm Oil, Forecasting, Time Series, Trend, Export.

\section{PENDAHULUAN}

Kegiatan ekspor impor didasari oleh kondisi bahwa tidak ada suatu negara yang benar-benar mandiri karena satu sama lain saling membutuhkan dan saling mengisi. Setiap negara memiliki karakteristik yang berbeda, baik sumberdaya alam, iklim, geografi, demografi, struktur ekonomi, maupun struktur sosial. Perbedaan tersebut menyebabkan perbedaan komoditas yang dihasilkan, komposisi biaya yang diperlukan, serta kualitas dan kuantitas produk. Adanya interdepedensi kebutuhan itulah yang menyebabkan adanya perdagangan internasional. Setiap negara memiliki keunggulan dan kekurangan. Komoditas yang dihasilkan suatu negara mungkin juga belum dapat dipakai langsung karena berupa bahan mentah yang memerlukan pengolahan lebih lanjut. Bahan mentah tersebut selanjutnya dibutuhkan negara lain sebagai bahan baku pabriknya. Secara langsung atau tidak, diperlukan pertukaran barang dan/atau jasa antarnegara dalam bentuk suatu hubungan perdagangan untuk memenuhi kebutuhan tiap-tiap negara tersebut.

Sub sektor perkebunan merupakan sub sektor yang memberikan kontribusi terbesar dalam ekspor komoditas pertanian, utamanya disumbang dari komoditas kelapa sawit sebesar US\$ 19 milyar.
Hal ini menunjukkan bahwa kelapa sawit merupakan komoditas perkebunan unggulan dan utama Indonesia. Tanaman ini memiliki nilai ekonomis tinggi dan menjadi penyumbang devisa negara yang terbesar dibandingkan dengan komoditas perkebunan lainnya.

Prospek pasar minyak sawit masih sangat cerah karena masih tingginya permintaan dunia. Minyak sawit mempunyai berbagai keunggulan dibandingkan dengan minyak nabati lain baik dari aspek keragaman produk yang dapat dihasilkan, aspek nutrisi, kesehatan, produktivitas, efisiensi maupun harga. Dengan keunggulan sifat yang dimilikinya, minyak kelapa sawit memiliki daya saing yang tinggi. Potensi komoditi kelapa sawit Indonesia dilihat dari sisi komparatif memiliki prospek yang baik, karena iklim serta cuaca Indonesia yang cocok untuk budidaya kelapa sawit. Indonesia sebagai negara tropis yang mendapat sinar matahari melimpah sepanjang tahun dengan curah hujan yang cukup dan hampir merata, kondisi mikroklimat inilah yang sangat dibutuhkan oleh tanaman kelapa sawit.

Perkembangan produksi kelapa sawit dunia dalam wujud Crude Palm Oil (CPO) sepanjang tahun 1980-2012 cenderung meningkat. Jika pada tahun 1980 produksi CPO dunia hanya sebesar 29,86 juta ton, maka pada akhir tahun 2012 
produksi CPO dunia tercatat sebesar 249,53 juta ton. Produksi CPO dunia dikuasai oleh dua negara, yaitu Indonesia dan Malaysia. Berdasarkan data FAO, selama tahun 2008-2012 Indonesia berada di posisi pertama sebagai negara penghasil $\mathrm{CPO}$ terbesar di dunia dengan rata-rata kontribusi produksi sebesar $44,46 \%$ dari total produksi CPO dunia,

Untuk perkembangan volume ekspor dan impor kelapa sawit dunia dalam bentuk minyak sawit (CPO) juga menunjukkan kecenderungan meningkat dari tahun ke tahun. Berdasarkan data FAO, pada periode tahun 2007-2011 terdapat dua negara eksportir CPO terbesar di dunia yang secara kumulatif memberikan kontribusi sebesar $85,37 \%$ terhadap total volume ekspor minyak sawit di dunia, yaitu Indonesia dan Malaysia. Indonesia berada di peringkat pertama negara eksportir minyak sawit terbesar di dunia dengan ratarata kontribusi sebesar $42,99 \%$ dari total ekspor minyak sawit dunia.

Perkembangan volume ekspor kelapa sawit Indonesia pada tahun 1981-2014 cenderung terus meningkat dengan pertumbuhan ratarata sebesar $25,10 \%$ per tahun. Jika pada tahun 1981 volume ekspor kelapa sawit Indonesia hanya sebesar 201,25 ribu ton dengan nilai ekspor sebesar US\$ 108,85 juta, maka tahun 2014 volume ekspor meningkat menjadi 24,37 juta ton senilai US\$ 19 milyar. Perkembangan volume dan nilai ekspor kelapa sawit Indonesia tahun 1981-2014 dapat dilihat pada Gambar 1.

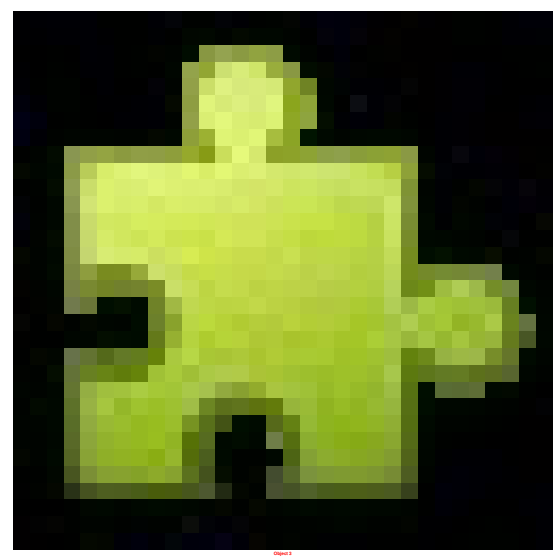

Gambar 1. Perkembangan Volume dan Nilai Ekspor Kelapa Sawit Indonesia Tahun 1981-2014

Mengingat pentingnya peran komoditas kelapa sawit bagi perekonomian Indonesia, maka perlu diketahui gambaran prospek perkembangan ekspor kelapa sawit di masa yang akan datang, hal tersebut bisa dilihat melalui peramalan volume ekspor kelapa sawit Indonesia. Aktivitas manajerial khususnya dalam proses perencanaan, seringkali membutuhkan pengetahuan tentang kondisi yang akan datang. Pengetahuan ini sering dinyatakan dalam bentuk peramalan kejadian atau kondisi yang akan datang.

Kegiatan

peramalan merupakan landasan penting agar 
para pengambil keputusan mampu menerapkan keputusan yang tepat dan dapat mengalokasikan sumberdaya organisasi secara efektif dan efisien. Hal ini dapat membantu para pelaku usaha kelapa sawit, pemerintah maupun lembaga terkait lainnya dalam menentukan kebijakan mengenai kelapa sawit.

Berdasarkan

data

perkembangan volume ekspor kelapa sawit Indonesia dapat dilihat bahwa data tersebut menunjukkan pola kecenderungan meningkat (trend meningkat). Oleh karena itu, perlu dilakukan peramalan menggunakan metode yang sesuai untuk pola data trend. Berdasarkan latar belakang tersebut, maka tujuan penelitian ini adalah untuk mengetahui metode peramalan yang paling sesuai untuk meramalkan volume ekspor kelapa sawit Indonesia dan untuk mengetahui nilai ramalan volume ekspor kelapa sawit Indonesia pada tahun 2016-2020.

\section{METODOLOGI PENELITIAN}

\subsection{Waktu dan Tempat Penelitian}

Penelitian ini menggunakan data volume ekspor kelapa sawit Indonesia. Jenis data yang digunakan dalam penelitian ini adalah data sekunder. Data yang dikumpulkan yaitu data time series volume dan nilai ekspor kelapa sawit Indonesia dari tahun 1981-2014 dan data lain yang terkait. Penelitian dilakukan pada bulan Maret sampai dengan April 2016.

\subsection{Metode Analisis Data}

Dalam penelitian ini, tahapan peramalan yang dilakukan yaitu mengumpulkan data, menentukan metode yang digunakan, menganalis data menggunakan metode-metode yang sudah ditentukan. Setelah itu, menghitung kesalahan ramalan dari masing-masing metode dengan menggunakan MAD dan MAPE, kemudian menentukan metode terbaik (yang memiliki nilai kesalahan ramalan terkecil) dan menghitung nilai ramalan volume ekspor kelapa sawit Indonesia untuk lima tahun mendatang, yaitu pada tahun 2016-2020 menggunakan metode terbaik tersebut.

\subsubsection{Metode Peramalan}

Metode peramalan yang digunakan dalam penelitian ini adalah metode Semi Rata-Rata (Semi Average Method), Trend Moment dan Regresi Linier Sederhana (Simple Linear Regression). Data yang dianalisis dengan metode Semi RataRata dan Trend Moment dihitung secara manual, sedangkan data yang dianalisis dengan metode Regresi Linier Sederhana menggunakan software SPSS 17.0.

\subsubsection{Metode Perhitungan Kesalahan Ramalan \\ Untuk memilih metode} peramalan terbaik yaitu dengan menghitung kesalahan ramalan yang dilihat dari nilai Mean Absolute Deviation (MAD) dan Mean Absolute Percentage Error (MAPE) dari masing-masing metode peramalan yang digunakan, semakin kecil nilai kesalahan ramalan maka semakin baik metode peramalan yang digunakan untuk meramalkan volume ekspor kelapa sawit Indonesia.

III. HASIL DAN PEMBAHASAN 
3.1. Perkembangan Volume Ekspor Kelapa Sawit Indonesia

Ekspor kelapa sawit Indonesia dikelompokkan menjadi empat jenis berdasarkan kode HS (Harmony System) yaitu:

1. Kode HS 151110000 : Minyak Sawit (Crude Palm Oil)

2. Kode HS 151190000 : Minyak Sawit Lainnya (Other Palm Oil)

3. Kode HS 151321000 : Minyak Inti Sawit (Crude Oil of Palm Kernel)

4. Kode HS 151329000 : Minyak Inti Sawit Lainnya (Other Palm Kernel Oil)

Perkembangan volume ekspor kelapa sawit pada tahun 1981-2014 cenderung terus meningkat dengan pertumbuhan rata-rata sebesar $25,10 \%$ per tahun. Jika pada tahun 1981 volume ekspor kelapa sawit
Indonesia hanya sebesar 201,25 ribu ton dengan nilai ekspor sebesar US\$ 108,85 juta, maka tahun 2014 volume ekspor meningkat menjadi 24,37 juta ton senilai US\$ 19 milyar. Dari keempat jenis produk kelapa sawit yang paling besar volume ekspornya pada tahun 2014 adalah minyak sawit lainnya (Other Palm Oil) (HS 151190000) sebesar $70,43 \%$ dari total ekspor diikuti oleh ekspor minyak sawit (CPO) (HS $151110000)$ sebesar $23,50 \%$, minyak inti sawit lainnya (Other Palm Kernel Oil) (HS 151329000) sebesar $4,43 \%$ dan minyak inti sawit (PKO) (HS 151321000) sebesar 1,65\%. Perkembangan volume dan nilai ekspor kelapa sawit Indonesia tahun 1981-2014 dapat dilihat pada Gambar 2.

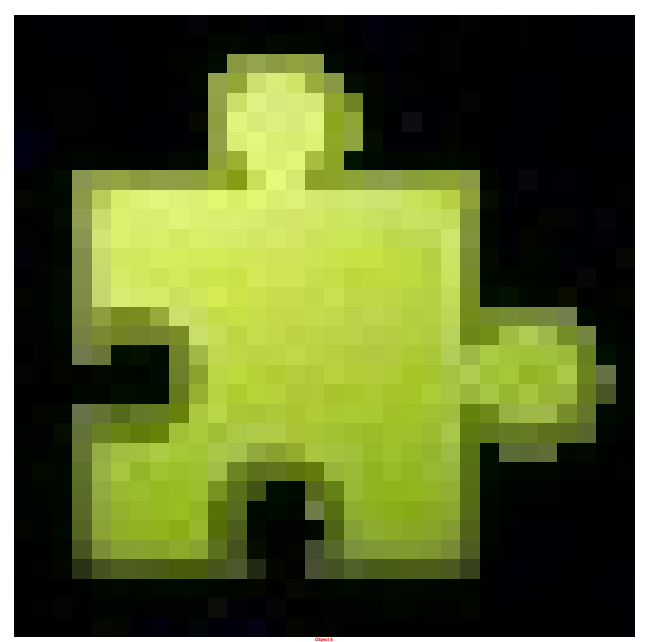

Gambar 2. Perkembangan Volume dan Nilai Ekspor Kelapa Sawit Indonesia Tahun 1981-2014

\subsection{Analsis Data}

Dari hasil analisis data yang dilakukan menggunakan metode Semi Rata-Rata, Trend Moment dan
Regresi Linier Sederhana diperoleh persamaan trend dari masing-masing metode tersebut yang dapat dilihat pada Tabel 1. 
Tabel 1. Nilai $a, b$ dan Persamaan Trend Masing-Masing Metode Peramalan

\begin{tabular}{lrrrc}
\hline \multicolumn{1}{c}{ Metode Analisis } & Nilai $a$ & Nilai & $b$ & Persamaan Trend \\
\hline 1. Semi Rata-rata & & & \\
- Tahun dasar 1989 & $1.139 .851,76$ & $706.331,24$ & $\mathrm{Y}^{\prime}=1.139 .851,76+706.331,24 \mathrm{X}$ \\
- Tahun dasar 2006 & $13.147 .482,88$ & $706.331,24$ & $\mathrm{Y}^{\prime}=13.147 .482,88+706.331,24 \mathrm{X}$ \\
2. Trend Moment & $-4.921 .593,68$ & $731.227,94$ & $\mathrm{Y}^{\prime}=-4.921 .593,68+731.227,94 \mathrm{X}$ \\
3. Regresi Linier Sederhana & $-5.652 .821,61$ & $731.227,94$ & $\mathrm{Y}^{\prime}=-5.652 .821,61+731.227,94 \mathrm{X}$ \\
\hline
\end{tabular}

Sumber: Data Sekunder, diolah

$\begin{array}{ccr}\text { Metode } & \text { Semi } & \text { Rata-Rata } \\ \text { merupakan metode } & \text { analisis }\end{array}$ dengan membentuk persamaan $Y^{\prime}=a+b X \quad$ yang dapat digunakan untuk mengetahui kecenderungan nilai suatu variabel dari waktu ke waktu dan dapat digunakan untuk meramalkan nilai suatu variabel tersebut pada suatu waktu tertentu. Dalam penerapannya semua data historis dibagi menjadi dua kelompok sama besar. Data yang dianalisis menggunakan metode ini adalah data volume ekspor kelapa sawit Indonesia dari tahun 1981-2014. Data tersebut berjumlah 34 periode yang dibagi menjadi dua kelompok, sehingga masingmasing kelompok berjumlah 17 periode. Kelompok 1 dari tahun 1981-1997 dan kelompok 2 dari tahun 1998-2014. Tahun pertengahan kelompok 1 yang dijadikan tahun dasar adalah tahun 1989 dan tahun pertengahan kelompok 2 yang dijadikan tahun dasar adalah tahun 2006. Nilai rata-rata hitung ( $a$ ) kelompok 1 untuk tahun dasar 1989 adalah 1.139.851,76 yang diperoleh dari penjumlahan volume ekspor dari tahun 1981-1997 dibagi dengan jumlah periode kelompok 1 yaitu 17. Nilai rata-rata hitung ( $a$ ) kelompok 2 untuk tahun dasar 2006 adalah $13.147 .482,88$ yang diperoleh dari penjumlahan volume ekspor dari tahun 19982014 dibagi dengan jumlah periode kelompok 2 yang juga 17 . Sedangkan nilai perubahan trend ( b ) adalah 706.331,24. Dari persamaan yang diperoleh diketahui $K_{2}-K_{1}>0$ yang berarti trend positif (meningkat).

Pemberian skor nilai $\mathrm{X}$ pada kelompok 1 (tahun 1981-1997) untuk tahun dasar 1989 dimulai dari -8 sampai 8 , sehingga skor nilai $\mathrm{X}$ pada tahun 1989 adalah 0 dan skor nilai $\mathrm{X}$ pada kelompok 2 (tahun 1998-2014) untuk tahun dasar 1989 dimulai dari 9 sampai 25. Sedangkan pemberian skor nilai $\mathrm{X}$ pada kelompok 1 untuk tahun dasar 2006 dimulai dari -25 sampai -9 dan skor nilai $X$ pada kelompok 2 untuk tahun dasar 2006 dimulai dari -8 sampai 8 , sehingga skor nilai 
X pada tahun 2006 adalah 0 . Hasil perhitungan menggunakan persamaan dengan tahun dasar 1989 ataupun persamaan dengan tahun dasar 2006 adalah sama, sehingga untuk perhitungan selanjutnya dapat menggunakan salah satu dari persamaan tersebut. Menurut Siagian dan Sugiarto (2006) keakuratan peramalan menggunakan metode Semi Rata-Rata akan semakin rendah bila periode peramalannya semakin jauh dari masa datanya.

Metode Trend Moment merupakan metode analisis yang dapat digunakan untuk keperluan peramalan dengan membentuk persamaan $Y=a+b X$. Dalam penerapannya, metode ini tidak mensyaratkan jumlah data harus genap atau ganjil. Dalam hal pemberian skor $X$ dimulai dari $0,1,2$, dan seterusnya (Siagian dan Sugiarto, 2006). Data yang dianalisis menggunakan metode ini adalah data volume ekspor kelapa sawit Indonesia dari tahun 19812014 yang berjumlah 34 periode, sehingga pemberian skor X dimulai dari 0 sampai 33.

Analisis regresi sederhana digunakan untuk memprediksi atau menguji pengaruh satu variabel independen ( $X$ ) terhadap variabel dependen $(Y)$. Analisis regresi linier sederhana terdiri dari satu variabel independen (predictor) dan satu variabel dependen (respon) (Raharjo, 2014). Data yang dianalisis menggunakan metode ini adalah data volume ekspor kelapa sawit Indonesia dari tahun 1981-2014 yang berjumlah 34 periode. Pemberian kode waktu ( $X$ ) dimulai dari 1, 2, 3, dan seterusnya. Dari hasil analisis Regresi Linier Sederhana menggunakan software SPSS 17.0 pada output Coefficients, pada kolom B pada Constant ( $a$ ) adalah $-5.652 .821,615$, sedangkan nilai Waktu $(b)$ adalah 731.227,939. Dari persamaan yang diperoleh dapat diterjemahkan konstanta ( a ) sebesar -5.652.821,615 menyatakan bahwa jika tidak ada nilai Waktu maka nilai

Volume sebesar $-5.652 .821,615$ ton. Koefisien regresi ( $b$ ) $X$ sebesar $731.227,939$ menyatakan bahwa setiap penambahan 1 nilai Waktu, maka nilai Volume bertambah sebesar 731.227,939 ton.

\subsection{Pemilihan Metode Peramalan Terbaik}

Pemilihan metode yang tepat dapat dilakukan dengan mengamati besarnya selisih nilai aktual pengamatan dengan nilai estimasi dari peramalan. Kriteria pemilihan metode terbaik dilihat dari nilai MAD dan MAPE dari masing-masing metode peramalan yang digunakan. Semakin kecil nilai kesalahan ramalan maka semakin baik metode peramalan yang digunakan. 
MAD adalah ukuran kesalahan peramalan keseluruhan untuk sebuah model, yaitu rata-rata selisih antara nilai yang diramalkan dan yang diamati (nilai aktual) (Hanke dan Wichern dalam Sanny dan Haryadi Sarjono, 2013). Menurut Sanny dan Haryadi Sarjono (2013) masalah yang terjadi dengan MAD adalah nilainya yang tergantung pada besarnya unsur yang diramal. Jika unsur tersebut dihitung dalam satuan ribuan, maka nilai MAD bisa menjadi sangat besar. Untuk menghindari masalah tersebut, dapat digunakan MAPE. MAPE dihitung sebagai rata-rata diferensiasi absolut antara nilai yang diramal dan nilai aktual, yang dinyatakan sebagai persentase nilai aktual. Nilai MAD dan MAPE masingmasing metode peramalan dapat dilihat pada Tabel 2.

Tabel 2. Nilai MAD dan MAPE Masing-Masing Metode Peramalan

\begin{tabular}{llr}
\hline \multicolumn{1}{c}{ Metode Analisis } & MAD & MAPE \\
\hline 1. Semi Rata-rata & $2.993 .848,29$ & 2,79 \\
2. Trend Moment & $3.007 .761,15$ & 3,02 \\
3. Regresi Linier Sederhana & $3.007 .761,15$ & 3,02 \\
\hline
\end{tabular}

Sumber: Data Sekunder, diolah

Dari Tabel 2 dapat dilihat bahwa metode peramalan yang memiliki nilai MAD dan MAPE terkecil adalah metode Semi RataRata dengan nilai MAD sebesar 2.993.848,29 dan nilai MAPE sebesar 2,79\%, sehingga dapat disimpulkan bahwa metode peramalan yang paling sesuai untuk meramalkan volume ekspor kelapa sawit Indonesia adalah metode Semi Rata-Rata. Hasil penelitian ini senada dengan penelitian yang dilakukan oleh Taufik (2009) yang menyatakan bahwa berdasarkan kriteria MAD menunjukkan bahwa hasil peramalan penjualan dengan metode Moving Average periode 5 bulan memiliki penyimpangan terkecil dari dua metode lainnya dan hasil peramalan menggunakan metode ini mendekati angka penjualan riil pada periode yang sama dengan periode yang diramalkan, berarti metode Moving Average 5 bulan paling baik daripada metode lainnya.

Metode peramalan yang memiliki nilai MAD dan MAPE terkecil adalah metode Semi RataRata dengan nilai MAD sebesar 2.993.848,29 dan nilai MAPE sebesar 2,79\%, sehingga dapat disimpulkan bahwa metode peramalan yang paling sesuai untuk meramalkan volume ekspor kelapa sawit Indonesia adalah metode Semi Rata-Rata. Hasil penelitian ini senada dengan penelitian yang dilakukan oleh Taufik (2009) yang menyatakan bahwa berdasarkan kriteria MAD menunjukkan bahwa hasil peramalan penjualan dengan metode Moving Average periode 5 
bulan memiliki penyimpangan terkecil dari dua metode lainnya dan hasil peramalan menggunakan metode ini mendekati angka penjualan riil pada periode yang sama dengan periode yang diramalkan, berarti metode Moving Average 5 bulan paling baik daripada metode lainnya.

\subsection{Nilai Ramalan Volume Ekspor Kelapa Sawit Indonesia}

Dari pemilihan metode terbaik yang telah dilakukan, maka metode Semi Rata-Rata yang terpilih menjadi metode peramalan terbaik untuk meramalkan volume ekspor kelapa sawit Indonesia berdasarkan kelayakan yang dimilikinya. Nilai ramalan volume ekspor kelapa sawit Indonesia untuk tahun 2016-2020 menggunakan metode Semi RataRata dapat dilihat pada Tabel 3.

Tabel 3. Nilai Ramalan Volume Ekspor Kelapa Sawit Indonesia Tahun 2016-2020 Menggunakan Metode Semi Rata-Rata

\begin{tabular}{crr}
\hline Tahun & $\begin{array}{c}\text { Nilai Ramalan } \\
\text { (Ton) }\end{array}$ & $\begin{array}{c}\text { Pertumbuhan } \\
(\mathbf{\%})\end{array}$ \\
\hline 2016 & $20.210 .795,30$ & \\
2017 & $20.917 .126,55$ & 3,49 \\
2018 & $21.623 .457,79$ & 3,38 \\
2019 & & \\
2020 & $22.329 .789,03$ & 3,27 \\
$\sum$ & $23.036 .120,27$ & 3,16 \\
\hline Rata-Rata & & $\mathbf{1 3 , 3 0}$ \\
\cline { 3 - 3 }
\end{tabular}

Sumber: Data Sekunder, diolah

Berdasarkan ramalan terlihat bahwa terdapat kecenderungan kenaikan volume ekspor kelapa sawit dari tahun 2016 sampai 2020 dengan pertumbuhan rata-rata sebesar 3,33\% per tahun. Pada tahun 2016 diperkirakan volume ekspor kelapa sawit Indonesia adalah sebesar 20.210.795,3 ton, tahun 2017 sebesar 20.917.126,55 ton, tahun 2018 sebesar 21.623.457,79 ton, tahun 2019 sebesar 22.329.789,03 ton dan tahun 2020 sebesar 23.036.120,27 ton. Nilai ramalan volume ekspor kelapa sawit Indonesia lebih rendah dibandingkan nilai aktual pada tahun 2014, hal ini diduga karena selama 34 periode volume ekspor cenderung terus meningkat setiap tahun yang menyebabkan besarnya selisih nilai volume ekspor pada tahun 1981 dengan tahun 2014 meskipun selama periode tersebut terjadi beberapa kali fluktuasi. Hal ini mempengaruhi persamaan trend pada metode yang digunakan untuk meramalkan nilai volume ekspor kelapa sawit Indonesia. Volume ekspor kelapa sawit Indonesia tahun 1981-2020 dapat dilihat pada Gambar 3. 


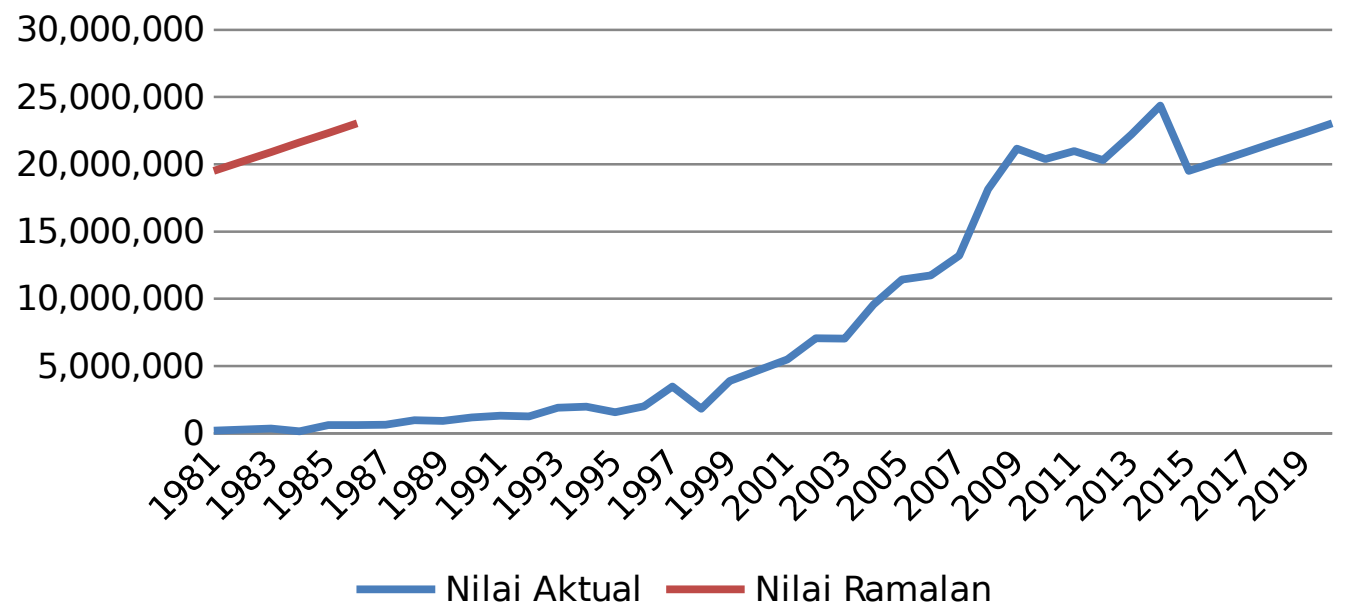

Gambar 3. Volume Ekspor Kelapa Sawit Indonesia Tahun 1981-2020

Hasil penelitian ini juga sesuai dengan penelitian yang dilakukan oleh Anggit Y.A.D dkk (2012) yang menunjukkan bahwa volume ekspor CPO Indonesia pada tahun 20132015 mengalami peningkatan, yaitu pada tahun 2013 sebesar 10.360 .656 $\mathrm{kg}$, tahun 2014 sebesar 10.824 .992 $\mathrm{kg}$, dan pada tahun 2015 sebesar 11.289.328 kg. Dari Gambar 11. terlihat bahwa prospek ekspor komoditas kelapa sawit untuk lima tahun ke depan masih sangat cerah yang berarti Indonesia memiliki potensi yang besar untuk terus berperan dalam pasar dunia. Gambaran ini dapat menjadi acuan bagi pemerintah, pelaku usaha kelapa sawit serta pihak terkait lainnya untuk mempertahankan bahkan terus meningkatkan kinerja ekspor kelapa sawit Indonesia. Menurut Indonesia Investments (2016) minyak sawit adalah salah satu minyak yang paling banyak dikonsumsi dan diproduksi di dunia. Dalam jangka panjang, permintaan dunia akan minyak sawit menunjukkan kecenderungan meningkat sejalan dengan jumlah populasi dunia yang bertumbuh dan karenanya meningkatkan konsumsi produk-produk dengan bahan baku minyak sawit.

\section{KESIMPULAN DAN SARAN 4.1. Kesimpulan}

Berdasarkan hasil penelitian yang dilakukan, maka diperoleh kesimpulan sebagai berikut:

1. Metode peramalan yang paling sesuai untuk meramalkan volume ekspor kelapa sawit Indonesia adalah metode Semi Rata-Rata berdasarkan kelayakan yang dimilikinya (memiliki nilai MAD dan MAPE terkecil dibandingkan dengan metode lainnya) dengan nilai MAD sebesar 2.993.848,29 dan nilai MAPE sebesar $2,79 \%$.

2. Berdasarkan perhitungan menggunakan metode Semi RataRata diketahui bahwa volume ekspor kelapa sawit Indonesia pada lima periode mendatang yaitu periode 2016 sampai 2020 mengalami peningkatan dengan pertumbuhan rata-rata sebesar $3,33 \%$ per tahun, tahun 2016 sebesar 20.210.795,3 ton, tahun 2017 sebesar 20.917.126,55 ton, tahun 2018 sebesar 21.623.457,79 ton, tahun 2019 sebesar 
22.329.789,03 ton dan tahun 2020 sebesar 23.036.120,27 ton.

\subsection{Saran}

Saran yang dapat diberikan berkaitan dengan hasil penelitian ini adalah sebagai berikut:

1. Pemerintah serta stakeholder lainnya dapat mendukung kinerja ekspor kelapa sawit Indonesia melalui perumusan dan penetapan kebijakan yang tepat, sehingga dapat mempertahankan bahkan terus meningkatkan kinerja ekspor kelapa sawit Indonesia.

2. Untuk penelitian selanjutnya dapat dilakukan peramalan untuk masing-masing jenis produk kelapa sawit (minyak sawit, minyak sawit lainnya, minyak inti sawit dan minyak inti sawit lainnya) yang diekspor dan perlu dianalisis mengenai variabelvariabel yang mempengaruhi volume ekspor kelapa sawit Indonesia selain variabel waktu. Selain itu juga perlu dilakukan peramalan menggunakan metodemetode lain untuk peramalan jangka menengah dan jangka pendek serta akan lebih baik jika dikombinasikan dengan peramalan kualitatif agar hasil peramalan lebih mendekati kenyataan.

\section{DAFTAR PUSTAKA}

Anggit Y.A.D, Rashid, dkk. 2012. Analisis Daya Saing Crude Palm Oil (CPO) Indonesia di Pasar Internasional. Jurnal SEPA : Vol. 9 No. 1 September 2012 : $125-133$. Universitas Pembangunan Nasional "Veteran". Yogyakarta
Badan Pusat Statistik. 2014. Statistik Kelapa Sawit Indonesia 2014. Jakarta

Badan Pusat Statistik. 2015. Statistik Indonesia 2015. Jakarta

Direktorat Jenderal Perkebunan. 2014. Statistik Perkebunan Indonesia Komoditas Kelapa Sawit 2013-2015. Jakarta

Pusat Data dan Sistem Informasi Pertanian Sekretariat Jenderal-Kementerian Pertanian. 2014. Outlook Komoditi Kelapa Sawit. Jakarta

Pusat Data dan Sistem Informasi Pertanian-Kementerian Pertanian. 2015. Buletin Triwulanan Ekspor Impor Komoditas Pertanian Volume VII No. 1 Tahun 2015. Jakarta

Raharjo, Sahid. 2014. Uji Regresi Sederhana dengan SPSS Lengkap.

http://www.konsistensi.com/2 014/06/uji-regresi-sederhanadengan-spss.html. Diakses pada tanggal 11 Februari 2016

Sanny, Lim dan Haryadi Sarjono. 2013. Peramalan Jumlah Siswa/i Sekolah Menengah Atas Swasta Menggunakan Enam Metode Forecasting. Jurnal Forum Ilmiah : Vol. 10 No. 2 Mei 2013 : 198 - 208. Binus University. Jakarta

Siagian, Dergibson dan Sugiarto. 2006. Metode Statistika untuk Bisnis dan Ekonomi. Jakarta: Gramedia Pustaka Utama. 
Taufik, Iqbal. 2009, Peramalan

Skripsi. Universitas

Penjualan CPO pada PT.

Dutapalma Nusantara.

Gunadarma. Depok 
